\title{
ESPAÇOS E PRÁTICAS FUNERÁRIAS NOS CAMPOS DA LUSITÂNIA ROMANA E TARDO-ANTIGA
}

\section{Funerary spaces and practices in the fields of Roman and Late Roman Lusitania}

\author{
ANDRÉ CARNEIRO \\ Dpto. de História da Universidade de Évora, Investigador do CHAIA-UÉ e do CECH/FLUC. \\ Mónica Rolo \\ Investigadora do Centro de Arqueologia da Universidade de Lisboa (UNIARQ).
}

Recibido: 27/09/2018

Revisado: 24/05/2019
Aceptado: 29/05/2019

Publicado: 05/07/2019

\section{RESUMO}

$\mathrm{O}$ mundo funerário romano e tardo romano na província da Lusitânia, e no Alto Alentejo em particular, apresenta significativos desequilíbrios, na maioria originadas pela falta de investigação específica sobre o tema. No entanto, conseguimos entrever um panorama de significativas continuidades, embora também com rupturas, na escolha dos locais e formas de tumulação, bem como na construção de uma geografia tumular na região.

\section{PalaVRas-ChaVe}

Lusitania; Mundo funerário romano; Antiguidade Tardia.

\section{ABSTRACT}

Roman and Late Roman funerary world in $\mathrm{Lu}$ sitania, and particularly in Alto Alentejo, presents major variations, due specially to the absence of a specific research in the subject. However, we can perceive an important stability, with major shifts in some cases, in the places and funerary practices chosen, and also in the regional funerary geography.

\section{KEYWORDS}

Lusitania; Roman funerary world; Late Antiquity.

ampc@uevora.pt 


\section{O MUNDO FUNERÁRIO ROMANO NA LUSITANIA -}

\section{PROBLEMÁTICA}

No panorama da investigação sobre o mundo rural, a esfera do universo funerário será porventura a que continua a colocar mais problemas de conhecimento. De forma resumida, pois o assunto já foi por nós tratado em anteriores ocasiões ${ }^{1}$, existe um paradoxo de base: salvo situações específicas, as deposições funerárias encontram-se hoje invisíveis na paisagem, porque estão ocultas no subsolo, contrariando totalmente a sua intenção original (que procurava a visibilidade para a rememoriação dos defuntos). Passam, portanto, despercebidas mesmo ao prospector mais experimentado, ao contrário do que sucede com a esmagadora maioria dos vestígios arqueológicos de pontos de povoamento ou laboração, que deixam um registo de superfície identificável. Este facto tem uma consequência natural: em regra, a detecção de contextos funerários ocorre aquando da sua destruição, o que origina duas situações - a aleatoriedade dos novos dados, que não reflecte a cartografia da topografia funerária antiga; e também a impreparação de muitas intervenções, que não dispõem, nem dos meios, nem das condições adequadas para conduzir o processo até ao resultado final pretendido (a publicação).

Quando se verificaram projectos de investigação que englobam em simultâneo os pontos de povoamento (nomeadamente os centrados em villae) e os âmbitos funerários relacionáveis, verifica-se que a escavação de sepulturas ou necrópoles não beneficia da mesma atenção da que é dedicada aos contextos habitacionais. $\mathrm{O}$ caso de Torre de Palma (Monforte), adiante analisado, é paradigmático. Como foi tratado em outra ocasião ${ }^{2}$, verifica-se que não existe qualquer documento de síntese que faça o elenco das sepulturas e espaços funerários intervencionados pelos diferentes arqueólogos que, em diversos momentos, foram os responsáveis pela investigação, sendo extremamente complexo analisar os dados existentes. É certo que esta situação não é exclusiva da Lusitania pois, por sistema, observa-se que o privilégio é sempre concedido às áreas habitacionais, ficando a esfera funerária na penumbra ${ }^{3}$.

1 Rolo, 2010; Carneiro, 2015, 125-126.

2 Carneiro, 2015, 128-129. É paradoxal comparar o volume de informações existentes sobre a pars urbana da vi$l l a$, os seus mosaicos ou as componentes paleocristãs, com o quase nulo volume de informação existente sobre as realidades funerárias no local.

3 Chavarría Arnau $(2007,192)$ menciona o exemplo da villa de Fortunatus (Fraga, Huesca), na qual várias zonas
Por estes motivos, conhecer o mundo funerário da Lusitania é uma tarefa complexa. Em virtude de a maioria das intervenções não serem planeadas, mas fruto do acaso, origina-se um acentuado desequilíbrio entre o conhecimento dos espaços de vida (regra geral mais fáceis de detectar), e as sepulturas e necrópoles. Da mesma forma, existem acentuadas variações regionais, originadas pela maior atenção ou pela presença de um arqueólogo que prontamente identifique as ocorrências. Por exemplo, considerando apenas o concelho de Elvas, Abel Viana identificou 12 contextos sepulcrais, o que significa um quinto de todo o total referenciado para os 15 concelhos do Alto Alentejo (54 sítios), o que por si só ultrapassa largamente o conhecido para toda a área dos territórios de Ebora Liberalitas Iulia/Évora e Pax Iulia/Beja, duas urbes que teriam várias necrópoles suburbanas e rurais na sua envolvente, mas onde os contextos funerários são muito mal conhecidos. Finalmente, entre outras consequências possíveis, note-se que está por construir uma tradição de investigação, não existindo intervenientes especializados. Não existe uma lógica de continuidade, o que também impede que se construam debates a partir da apresentação de resultados que a posteriori podem ser analisados sob a forma de sínteses, como se verifica em vários outros territórios (cite-se, como exemplo, o caso da Baetica ${ }^{4}$. Os trabalhos de terreno decorrem de modo irregular, fruto de ciclos ditados mais pela disponibilidade pessoal que por dinâmicas sustentadas ou um projecto sistemático, pelo que se observam longos hiatos entrecortados pela acção de algum dos poucos investigadores disponíveis.

De modo paradoxal, estes desequilíbrios acentuaram-se desde 1993, a data em que em outro texto se marcou o final de "um ciclo notável" ${ }^{5}$. Apesar da in-

funerárias hoje desaparecidas foram escavadas sem que se produzisse documentação. Consultando o seu catálogo respeitante às villae tardo-antigas, mais casos emergem.

4 Vaquerizo Gil, 2002; veja-se o texto de síntese em 2011. Em 2017, Felix Teichner procedeu a uma abordagem genérica que constitui um excelente balanço da situação. Para o Alto Alentejo, note-se que existe um estudo paradigmático e de enorme alcance, da autoria da Helena Frade e José Carlos Caetano (1993), ainda hoje o único documento de síntese regional em todo o território português.

5 Sobre o tema veja-se Carneiro, 2015, 125-126. Referimo-nos em concreto à fase datada entre 1973 e 1993, na qual decorreram importantes intervenções arqueológicas em diversas sepulturas e necrópoles, culminando com um artigo fundamental para o conhecimento do mundo funerário no Alto Alentejo, da autoria de Helena Frade e José Carlos 
tegração de arqueólogos nos quadros das autarquias onde, pelo menos em teoria, estão mais próximos das realidades territoriais, e do enquadramento legislativo que inclusivamente obriga à presença de antropólogos aquando da realização de exumações em contextos sepulcrais ${ }^{6}$, verificamos que não aumentou o número de intervenções arqueológicas programadas de âmbitos funerários em meio rural, nem se incrementou o número de case studies que sirvam como modelos de referência pela sua exemplar escavação, interpretação e publicação, nem sequer se procedeu a uma melhor afinação das metodologias de detecção de ambientes funerários em trabalhos de prospecção, visto que, com raras excepções ${ }^{7}$, estes continuam a não constar das cartas e levantamentos arqueológicos publicados. Sobre o mundo funerário lusitano continua a pairar um estranho silêncio, fruto de constrangimentos externos à investigação arqueológica, mas também de uma contínua incapacidade de mobilizar agentes preparados para a sua identificação e estudo (figura 1).

\section{O LABor de ABel Viana}

Embora o âmbito territorial considerado seja extensível à província da Lusitania, de modo a procurar fixar tendências e identificar paralelos, centramo-nos mais especificamente no actual território português a sul do rio Tejo e, de modo mais particular, no espaço geográfico definido como Alto Alentejo ${ }^{8}$. Este território, definido simultaneamente por limites naturais e por circunscrições administrativas actuais, apresenta o particular interesse de ter sido intensamente percorrido e, pontualmente, escavado durante as décadas de 40 e 50 do século XX por um arqueólogo atento às modificações da paisagem então em curso devido à mecanização agrícola: Abel Viana, que foi acompanhado neste seu labor por alguns agentes locais, entre os quais se destaca António Dias de Deus, funcionário da Colónia Correccional de Vila Fernando (Elvas). Esta intensa actividade traduziu-se na identificação de 22 sepulturas isoladas ou espaços de necrópole (correspondendo a cerca de 821 enterramentos e a um espólio que ascende a mais de um milhar de itens contabilizados), bem como na produção de

\section{Caetano (1993).}

6 Decreto-Lei 164 de 2014 que institui o Regulamento de Trabalhos Arqueológicos, Diário da República $1^{a}$ série $\mathrm{n}^{\mathrm{Q}}$ 213 de 4 de Novembro de 2014, art. ${ }^{\circ}$ 11, alínea 1 e 6.

7 Veja-se Almeida, 2000.

8 Veja-se Rolo, 2017, ponto 1.

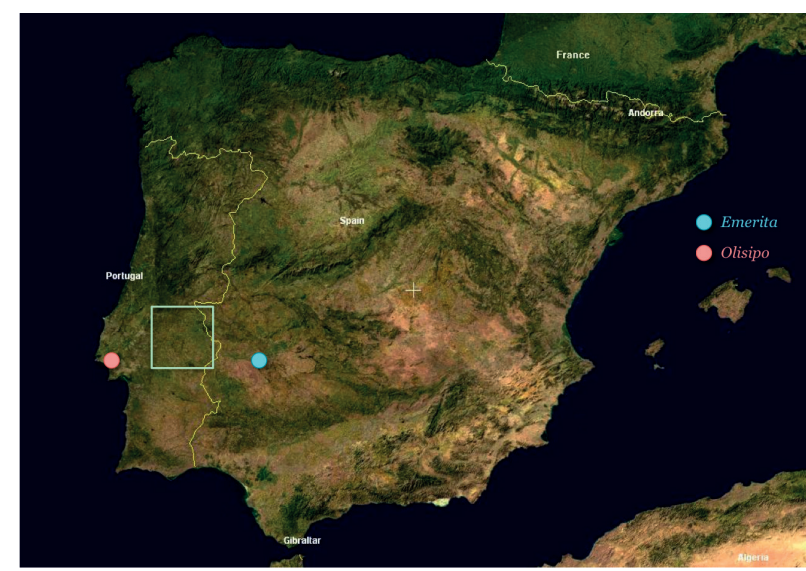

1. Mapa da Península Ibérica com localização do território alto alentejano (ङ 2018 Google Earth).

diversos artigos em publicações portuguesas e espanholas, fazendo da área sul do Alto Alentejo um caso de referência fundamental para a percepção das paisagens funerárias no território emeritense e lusitano9 (figura 2)

Durante este período, que podemos situar entre 1934 e 1955, há que distinguir duas fases. De 1934 a 1949 , os trabalhos foram conduzidos de forma sistemática, mas não metódica, por António Dias de Deus e seus colaboradores ${ }^{10}$. Funcionário da Colónia Correcional de Vila Fernando (Elvas) e amador de Arqueologia, encontrava-se em permanência no território, sendo alertado quando alguma descoberta acontecia, geralmente em contexto de trabalhos agrícolas. A sua acção era imediata, procedendo a escavações sem critérios metodológicos mas de forma extensiva, de modo a obter o maior volume de informação artefactual possível em cada contexto identificado. Como mais tarde escreveu Abel Viana, "Dias de Deus não procura escavar aqui e além, onde quer que suponha haver, ou tenha certeza de existirem antiguidades arqueológicas. Está atento às informações que recebe sobre o que o curso das lavouras vai descobrindo e ameaça destruir, assim como acode ao que saiba estar em maior risco de breve desaparecimento. E não é só a lavra para as sementeiras o motivo destas intervenções, mas também o arranque de arvoredo, as surribas, a abertura de caboucos, o rasgo de caminhos novos ou o alargamento dos antigos [...]”11.

A partir de 1949 temos a coordenação de Abel Viana, alertado para as 'pesquisas' promovidas a

9 Frade e Caetano, 1993; quantificação e avaliação da informação em Rolo, 2017.

10 Rolo, 2016, 85-86.

11 Viana, 1955, 7. 


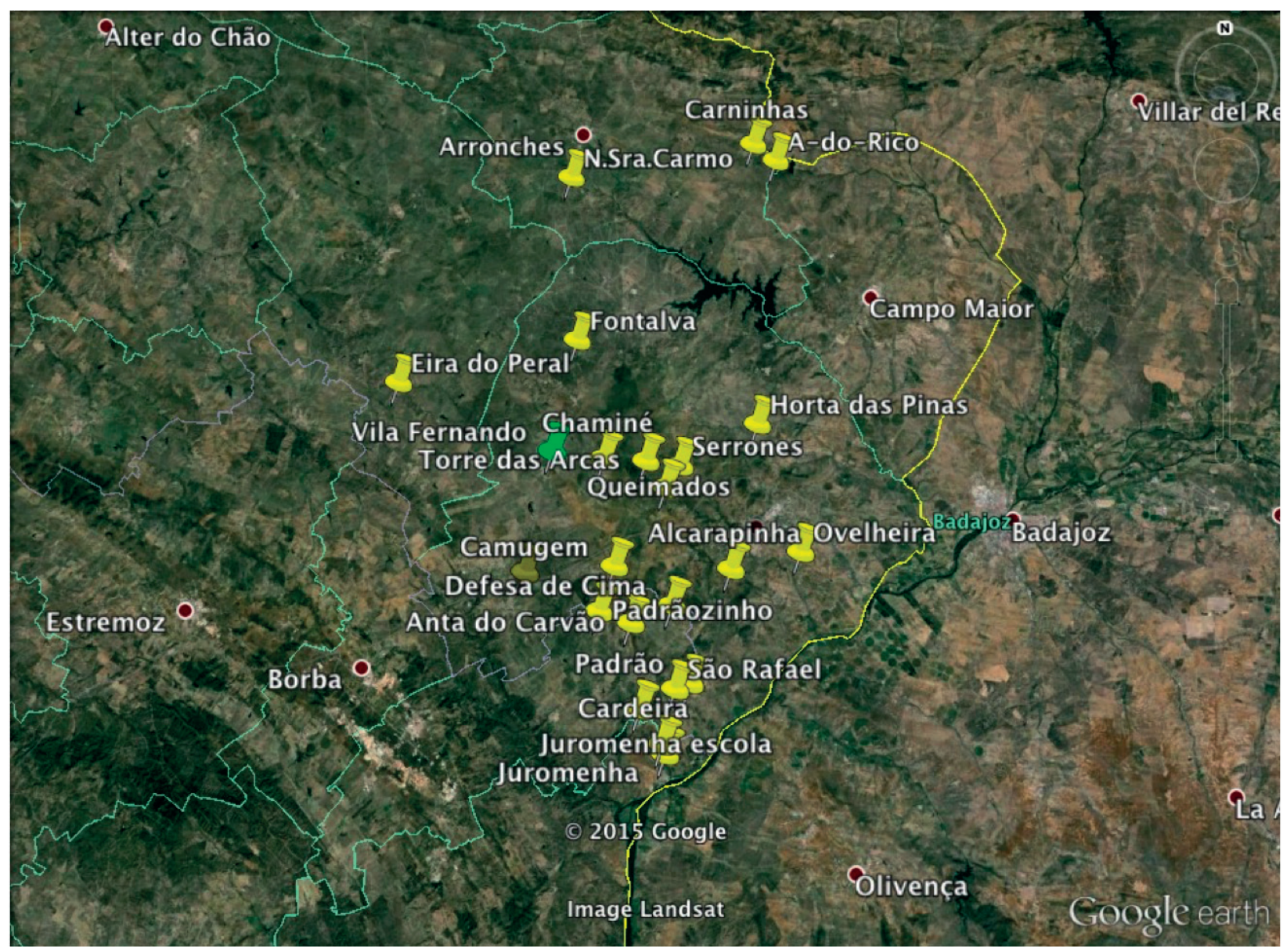

2. Localização das necrópoles referidas no Alto Alentejo (ㄷ 2018 Google Earth).

partir de Vila Fernando. O seu intuito seria, por um lado, organizar as escavações de acordo com critérios metodológicos e científicos mas, sobretudo, organizar o numeroso espólio proveniente dos trabalhos até então realizados. O labor de campo de Viana prolonga-se até 1955, ano em que cessam as escavações, mas terá continuidade até ao final da sua vida (1964), promovendo a inventariação do espólio e a sua divulgação, quer através de numerosos artigos científicos, quer na criação e organização da Secção Arqueológica da Fundação da Casa de Bragança, depositada no castelo de Vila Viçosa, onde ainda se mantém o essencial do conjunto em exibição pública ${ }^{12}$.

É certo que múltiplas questões rodeiam o contexto em que os trabalhos foram realizados, essencialmente pela impreparação metodológica e ausência de registos que caracterizam a primeira fase, na qual Abel Viana não estava presente, e em que

12 Sobre a intervenção de Abel Viana nas necrópoles alto-alentejanas, ver essencialmente Rolo, 2017.
António Dias de Deus e os seus colaboradores agiam sozinhos. O próprio arqueólogo de Viana do Castelo tinha noção destas limitações ${ }^{13}$, sendo o mérito da sua acção ainda maior porque, além dos trabalhos por si realizados, teve de organizar a informação obtida nesta primeira fase. Se a sua acção não foi na altura compreendida e acabou por ser alvo de fortes críticas ${ }^{14}$, e se durante muitos anos não foi devidamente reconhecida, é justo salientar que a quantidade de informação recolhida durante as suas intervenções na área de Elvas fornece um quadro de referência inigualável para o estudo do mundo funerário de época romana.

13 "Dias de Deus não tinha apontamentos das suas numerosas investigações, mas a sua viva memória permitiu que eu redigisse as seguintes notas." (Viana, 1950, 290).

14 “(...) por falta de um Diário de escavações, de fotografias, plantas e cortes, torna-se difícil fazer o estudo individualizado destes monumentos, (...). Direi, no entanto, que o seu espólio antropológico, de que nada resta, era digno de melhor destino" (Heleno, 1951, 84). 
A informação produzida por Abel Viana e seus colaboradores é tanto mais importante quanto não tem paralelo para o actual território português: nenhum investigador trabalhou tão intensamente sobre o mundo funerário em meio rural, situação ainda mais notável quanto sabemos que o arqueólogo vianense dedicou a sua atenção a múltiplos outros campos de estudo ${ }^{15}$. Inúmeras das múltiplas dúvidas que pairam sobre o espólio, suas condições de recolha e sua interpretação no âmbito dos contextos funerários, a informação recolhida é tanto mais útil quanto se refere a um território com uma larga tradição de investigação ${ }^{16}$, o que permite estabelecer uma cartografia do povoamento que possibilita a articulação entre os espaços de vida e a topografia funerária ${ }^{17}$.

Note-se que a relevância do labor de Abel Viana é ainda mais contrastante pois, nas décadas seguintes, os projectos de intervenção arqueológica são mais escassos e funcionam de modo desarticulado, quer inter-sítios (ou seja, sítios escavados por diversos protagonistas sem relação entre si), quer intra-sítio (na medida em que o mesmo sítio pode ser escavado sucessivamente por diferentes arqueólogos, mas sem continuidade na análise e na articulação do programa). Apesar dos bem intencionados esforços dos diversos agentes, nota-se que, após Abel Viana, os processos são conduzidos mais por acção de descobertas fortuitas do que de programas planificados, com as necessárias consequências na dificuldade de análise e percepção das realidades arqueológicas, como se comentará para cada caso em seguida.

\section{O TERRITÓRIO: PADRÕES DURANTE O MUNDO}

ROMANO

Embora dispondo de territórios intensamente prospectados, o Alto Alentejo continua a apresentar numerosas interrogações, quando se pretende construir uma leitura mais apurada dos fenómenos de evolução ao longo do mundo romano ${ }^{18}$. Na análise da cartografia do povoamento sobressai a ideia de um espaço onde as dinâmicas do povoamento rural são muito fortes, dada a escassez de centros

15 Sobre Abel Viana, veja-se Rolo, 2016, 84-91.

16 Almeida, 2000.

17 Carneiro, 2015; para alguns casos concretos, veja-se o volume II de Carneiro, 2014.

18 Sistematização da informação e análise em Carneiro, 2014, volume I; para a análise específico de cada âmbito municipal, veja-se o volume II. urbanos existentes - a urbs de Ammaia é bem conhecida, até do ponto de vista da evolução administrativa $^{19}$, mas numerosas dúvidas se levantam sobre o estatuto de Abelterium, mansio constante da via XIV do Itinerário de Antonino e que corresponde à actual localidade de Alter do Chão. Para além destes casos, não existem mais centros urbanos atribuídos a realidades arqueológicas, pelo que será provável que o mundo rural tivesse uma intensa dinâmica, beneficiando da passagem de três itinerários de vias principais e da proximidade à capital provincial, Augusta Emerita.

Contudo, se o mundo rural teria uma considerável capacidade de auto-organização e se as elites assumiriam uma notável capacidade empreendedora, como se demonstra pelas monumentais villae áulicas que pontuam a paisagem, há que ter em consideração que o mundo funerário assume uma assinalável discrição, pela ausência de sepulturas opulentas, de mausoléus, ou mesmo, de epigrafia que denuncie a ostentação derivada da pretendida visibilidade pública. Não se conhecem pedestais honoríficos e são raras as placas que poderiam ter sido encastradas em algum mausoléu ${ }^{20}$.

Por estes motivos, a invisibilidade das evidências funerárias parece ser contrastante com a monumentalidade dos espaços de vida. O panorama é, por isso, algo paradoxal, sendo de notar também que a densidade de locais de tumulação é muito inferior aos espaços de vida. A título de exemplo, compare-se o concelho de Elvas, onde Abel Viana concentrou a maior parte dos seus esforços para a detecção e escavação de sepulturas: do inventário recolhido

19 Mantas, 2000.

20 A ocorrência de mausoléus ou de monumentos funerários é extremamente rara no território do sul da $\mathrm{Lu}$ sitania. A villa de Milreu (Faro) tem uma estrutura que poderia cumprir estas funções, havendo outra semelhante em Cerro da Vila (Loulé), mas em ambos os casos, não se preservou qualquer epitáfio. $\mathrm{Na}$ epigrafia, temos algumas ocorrências: na área de Évora, a placa da villa da Tourega (IRCP 382), pelas dimensões e formulário, corresponde a uma estrutura sepulcral familiar de grande monumentalidade; o epitáfio atribuído a Vila Viçosa (IRCP 468) refere um munimentum que teria apreciáveis dimensões, assim servindo os propósitos da família que nele apôs um titvlum; eventualmente a placa proveniente de Herdade de Mateus (Monforte) (IRCP 578) poderá corresponder a um sepulcro familiar, talvez relacionado com a via XIV, cujo traçado se situa nas proximidades. Há ainda a considerar a inscrição da familia Preccia proveniente de S. Pedro de Almuro (Almor), em Monforte (IRCP 595a), que também poderá corresponder a uma tipologia deste tipo. 
em $2014^{21}$, verifica-se que existem 52 sítios de época romana, dos quais apenas 14 correspondentes a sepulturas/necrópoles (somente mais dois detectados desde os trabalhos de Viana), enquanto 38 são assinalados como sítios de habitação de variadas tipologias. Ou seja, para a região, o volume informativo de que dispomos para o mundo dos vivos é incomparavelmente superior, quer em termos qualitativos, quer quantitativos, ao existente na esfera funerária. Para o restante território, a proporção é ainda maior, cabendo em média uma ocorrência sepulcral para dez sítios de habitação, havendo extensos territórios para os quais não se regista qualquer identificação de um possível enterramento ou contexto funerário. Portanto, a geografia tumular é incomparavelmente menos conhecida do que a do povoamento.

Registe-se ainda que no mundo funerário alto-alentejano predomina a diversidade ${ }^{22}$. Se a cremação parece ser o rito com maior ocorrência numérica, a vantagem sobre a inumação não é expressiva, registando-se por vezes a coexistência de ambos os ritos na mesma necrópole, restando saber se existe uma contemporaneidade ou se um precede o outro. A maioria das necrópoles parece não estar organizada, quer nas orientações, quer na existência de eixos delimitadores, embora por vezes existam situações de maior regularidade. Da mesma forma, a arquitectura tumular é variada, com distintas ocorrências coabitando no mesmo espaço funerário, o que demonstra a forma como o meio rural albergava uma grande heterogeneidade de práticas. Como exemplo, ilustre-se o caso de Torre das Arcas, onde em 84 enterramentos escavados coexistem 16 tipologias construtivas distintas, com significativas variações formais ${ }^{23}$. Note-se que nenhuma das necrópoles consideradas foi escavada na totalidade, situação que é válida para todo o território do actual Alto Alentejo. O mesmo é válido para as oferendas funerárias, entre as quais, apesar das regularidades do conjunto bilha e jarro, associadas a púcaros, pratos ou malgas ${ }^{24}$, não se detectam normas ou frequências repetitivas. Paradoxalmente, é esta ausência de normas padronizadoras que confere um "ar de família" às necrópoles registadas em todo o território alentejano e mesmo lusitano, onde a diversidade é a norma, coexistindo no mesmo espaço

21 Carneiro, 2014, vol. II, 171-214.

22 Rolo, 2017; ver também Frade e Caetano, 1993.

23 Deus, Louro e Viana, 1955, 575; Rolo, 2017, figura 3.

24 Frade e Caetano, 1993, 867. diferentes formas de entendimento da deposição funerária.

Um dos aspectos mais notáveis do mundo funerário alto-alentejano é o significativo número de enterramentos contabilizados em algumas das necrópoles. De todos os espaços funerários, o mais numeroso parece ser o da Chaminé (Elvas), embora a situação seja algo enganadora, visto que os cerca de 226 enterramentos estimados correspondem a quase um milénio de tumulações, numa necrópole cujo arco diacrónico abarca desde o séc. IV a.C. até ao séc. VII d.C. ${ }^{25}$. Em Padrãozinho (Vila Viçosa) registam-se 189 enterramentos, embora também se possam individualizar quatro núcleos distintos, com significativas evoluções diacrónicas. Quanto a Serrones (Elvas), o total estimado ronda as 106 tumulações, sendo de registar que o sítio se encontra próximo do itinerário da via XII e junto a grandes villae nas imediações. Neste denso universo, ressalta a noção de extensas necrópoles pertencentes a trabalhadores rurais, visto que o espólio é geralmente estereotipado, com poucas ocorrências de materiais de excepção. Salienta-se o caso de Reguengo (Monforte) ${ }^{26}$, onde em sete sepulturas de incineração se regista um espólio notável pela diversidade, incluindo formas atípicas de terra sigillata hispânica, frequentemente grafitadas, o que indica a ocorrência de vários recipientes idênticos na mesma comunidade. Além da variedade de materiais, destaca-se a referência a um anel em ouro (recolhido mas entretanto perdido), o que reforça a noção de uma necrópole que poderia albergar pessoas de uma condição social superior. Talvez esta capacidade aquisitiva explique a ocorrência de vinte e duas peças de cerâmica na sepultura 2 e de vinte na 3 (em ambos os casos, com tipologias raras e atípicas), contrastando com outras sepulturas onde ocorrem apenas duas ou três peças, no que se torna uma variação difícil de explicar, mas que encontra paralelos em outra necrópole situada bem próximo, no caso, a de Pocilgais (Fronteira), na qual as três sepulturas registadas também detinham espólios em número e qualidade bem diversos ${ }^{27}$. Mais uma vez, esta diversidade é de difícil explicação, constituindo uma marca generalizada que caracteriza o mundo funerário romano em âmbito rural na província da Lusitania.

25 Sobre o caso específico da necrópole da Chaminé e as suas características, veja-se Rolo, 2017, ponto 3.

26 Carneiro, 2014: vol. II, 333-334, com bibliografia.

27 Carneiro, 2005. 
4. Evolução E transformação durante a AnTIGUIDADE TARDIA

Neste panorama podemos definir vários modelos de evolução a partir do século III, momento a partir do qual novas influências culturais e religiosas criam distintas transformações no registo social e funerário.

\subsection{Memoria e continuidade no registo funerário}

I) caso de estudo: Torre de Palma

As necrópoles envolventes à villa de Torre de Palma (Monforte) já foram objecto de uma análise própria $^{28}$, pelo que aqui se retoma apenas uma perspectiva geral.

A villa de Torre de Palma parece corresponder ao protótipo de um sítio habitado em continuidade durante vários séculos: reconhece-se o que poderá ter sido a fundação original do local, com um módulo habitacional em torno de um átrio, podendo corresponder a uma villa alto-imperial de tradição construtiva itálica. Ao seu lado irá desenvolver-se uma grande villa de peristilo, terminando em sala de tripla ábside, parecendo possível que os dois edifícios tivessem coexistido no tempo, dado o grau de preservação do primeiro espaço referido, embora sobre as escavações de Torre de Palma não tivesse ficado qualquer registo gráfico ou informação estratigráfica. A villa de peristilo regista alguns sinais de ocupação durante um largo período (embora possivelmente com descontinuidades), atendendo aos remendos em opus signinum no pavimento em mosaico do peristilo principal e a sinais de "squatterização" em alguns compartimentos. De qualquer forma, a posterior ocupação humana no local está comprovada, não apenas pela construção sucessiva de duas basílicas com um baptistério individualizado, mas também por inumações islâmicas e pela invocação a uma ermida de São Domingos que após a reconquista cristã aproveita uma das ábsides da basílica.

A este panorama corresponde uma evolução no espaço funerário que é igualmente difícil de ler, visto que (como nas áreas de actividade), os ambientes foram escavados por diferentes arqueólogos, mas sempre sem registos estratigráficos ou uma publica-

28 Carneiro, 2015. Sobre Curral de Sampão e Monte de Pombal, duas necrópoles nas proximidades da grande villa de Torre de Palma mas que possivelmente correspondem a pontos de povoamento secundário, ver 127 ; sobre a(s) necrópoles(s) próprias da villa, ver 128-129. ção cuidada. Em face dos dados perceptíveis, enumerem-se as ocorrências:

1. Cemitério "ao pé das ermidas”, a Norte: (...) Na própria villa de Torre de Palma, próximo da basílica, explorámos também um cemitério com sepulturas de incineração e inumação e abundante cerâmica." ${ }^{29}$ Decompondo a informação, percebe-se a existência de duas fases de tumulação, estando quatro sepulturas no interior de um edifício rectangular que pode corresponder a uma estrutura de tipo mausoléu, e outras 18 (algumas com mais do que um crânio, podendo ocorrer no mínimo 21 enterramentos), de diferentes épocas, com distintas orientações e conteúdos, na sua envolvente.

2. O cemitério "ao pé da estrada" escavado em Setembro de 1960, que apresenta uma “(...) sepultura de incineração; dentro dela encontrei as seguintes peças: 6 taças de cerâmica de terra sigillata, algumas com marcas, uma peça inteira de vidro, de feitio de garrafa e 6 peças de cerâmica vulgar. ." $^{\text {" }}$ Nos dias seguintes, mais enterramentos foram intervencionados, sem que fique claro quantos e com que espólio. Contudo, nesta mesma área, terão sido posteriormente identificadas duas sepulturas de inumação, sem espólio.

3. A situação mais delicada de analisar centra-se na área interior da basílica: aqui existem "[sepulturas] um pouco por toda a parte, dentro e fora das basílicas, excepto no baptistério"31. Porque o espaço basilical foi escavado por distintos arqueólogos, sempre sem qualquer planta ou descrição, torna-se complexo analisar a cartografia dos enterramentos, e inclusivamente torna-se claro que a equipa americana intervencionou enterramentos anteriormente escavados, duplicando assim alguma informação. De qualquer forma, existem alguns dados ${ }^{32}$ :

- uma sepultura em sarcófago orientada com uma das ábsides, contendo uma inumação onde está depositado um cadeado. É complexo definir a cronologia do enterramento e a causa pela qual ocupa uma posição de enorme centralidade na topografia funerária e simbólica do local;

- uma sepultura com fivela de cinturão de tipo visigótico na nave norte da basílica oriental;

- 4 sepulturas no interior da antiga ermida de $\mathrm{S}$.

29 Heleno, 1962, 314, nota 1.

30 Caderno de campo de 28.09.1960 de João Lino da Silva, depositado no Museu Nacional de Arqueologia.

31 Almeida, 1972-1974, 108

32 Enumeração em Carneiro, 2015, 128-129, com comentários. 
Domingos que podem corresponder a tumulações medievais ${ }^{33}$;

- de acordo com Thilo Ulbert ${ }^{34}$, um grupo de sepulturas sob o pavimento da segunda fase da basílica (oito no total) e sob o pavimento do baptistério (duas), a que se sobrepõem 16 sepulturas tardias, pouco profundas (Hochgräber), abertas no chão da basílica/baptistério após o seu abandono e alinhadas com as paredes (15 no interior do edifício, mais uma no baptistério). Desta forma, poderíamos ter três fases de tumulação: uma necrópole anterior à edificação do monumento cristão, portanto de época alto-imperial; uma fase contemporânea à utilização do local, e datável (pelas cerâmicas e fivela) em torno ao século VI; e uma posterior, relacionada com a ermida de São Domingos, ocorrendo em torno ao século XII/XIII.

4. O designado "cemitério sul", onde novamente existem sinais de ocupação prévia ao espaço funerário. Assim, foram identificadas três salas com piso de opus signinum e uma lareira com base em tijoleira. Orientadas com os muros, surgem 15 sepulturas rectangulares, havendo outras três que os cortam, o que indica que neste momento a memória do local já se havia perdido (enterramentos de época islâmica ou posterior).

É importante notar que, apesar das diversas designações para os "cemitérios", estes localizam-se todos na mesma área, distante do complexo residencial da villa. Em Torre de Palma, a pars urbana e o mundo dos mortos estão sempre distanciados. Contudo, na micro-topografia do sítio, observamos duas situações na zona funerária: uma geral e constante, onde os espaços sepulcrais se mantêm em continuidade; e uma variação, com a ocorrência de sepulturas que invadem áreas onde existiram estruturas em momentos anteriores. Que estruturas são essas é mais difícil de definir: seriam espaços funerários construídos, que assim mantêm a sua vocação, ou áreas funcionais de laboração, como o parece dar a entender o conjunto de salas com pavimentos em opus signinum? Da mesma forma, a construção da primeira basílica paleocristã provoca uma basculação na topografia funerária do local, que se irá orientar para este edifício, privilegiando as tumulações ad sanctos no interior do templo ou nas suas imediações; contudo, parece ser provável que a construção da basílica tenha sido feita sobre um espaço sepulcral anterior, a julgar por alguns indica-

33 Segundo proposta de T. Ulbert (1978). 341978. dores dispersos. Desta forma, a topografia funerária de Torre de Palma apresenta um conjunto de indicadores constantes, o que aliás provoca as evidentes confusões que os diversos arqueólogos sentiram no momento de individualizar tão diferentes enterramentos. A proliferação de designações e a desorganização interpretativa dos âmbitos funerários são, afinal, uma inesperada consequência da perenidade do espaço sepulcral neste sítio (figura 3).

II) caso de estudo: Chaminé

A necrópole de Chaminé (Elvas) já foi apresentada por nós em estudos separados ${ }^{35}$ como um importante exemplo de continuidade (embora com hiatos) na topografia funerária, especialmente se colocada em visão de conjunto com a villa de Carrão, que lhe fica próxima. Contudo, o arco cronológico transcende em muito o do sítio anexo, conforme anteriormente referido. Assim, enumere-se o conjunto de evidências disponíveis, tendo em consideração que Abel Viana menciona que apenas foi escavada uma parte da necrópole:

1. Embora as dificuldades de interpretação sejam muitas, porque apenas o espólio que se encontrava em boas condições foi recolhido, registam-se pelo menos 150 enterramentos em urna, com dois modos de deposição - em caixa formada por pequenas lajes e em covacho escavado no afloramento. Entre o rico espólio depositado, destacam-se alguns elementos metálicos dobrados ou partidos, evidenciando a prática do "rito destrutivo" comum até meados do século III a.C. ${ }^{36}$. Nos conjuntos cerâmicos, destaca-se a variedade morfo-tipológica, com ocorrências comuns em paralelos que percorrem todo o sudoeste peninsular desde Garvão até à zona de Cáceres. Ausente a cerâmica estampilhada, encontram-se fragmentos de uma peça aparentada com os fabricos ibéricos, denunciando redes de contacto favorecidas pela proximidade do rio Guadiana.

2. Em zona onde foram identificados três manchas de concentração de terra escura e cinzas, interpretadas como ustrina, foi escavada uma sepultura de cronologia alto-imperial. Pelo espólio - terra sigillata, vidros, uma moeda e cerâmica de paredes finas - o enterramento poderá pertencer ao final do século I e primeiros anos da centúria seguinte.

35 Carneiro, 2015, 129-130; Rolo, 2017, ponto 3, em ambos com as referências bibliográficas para os enterramentos da Chaminé e para a villa do Carrão.

36 Jímenez Díez, 2006, 88-89. 


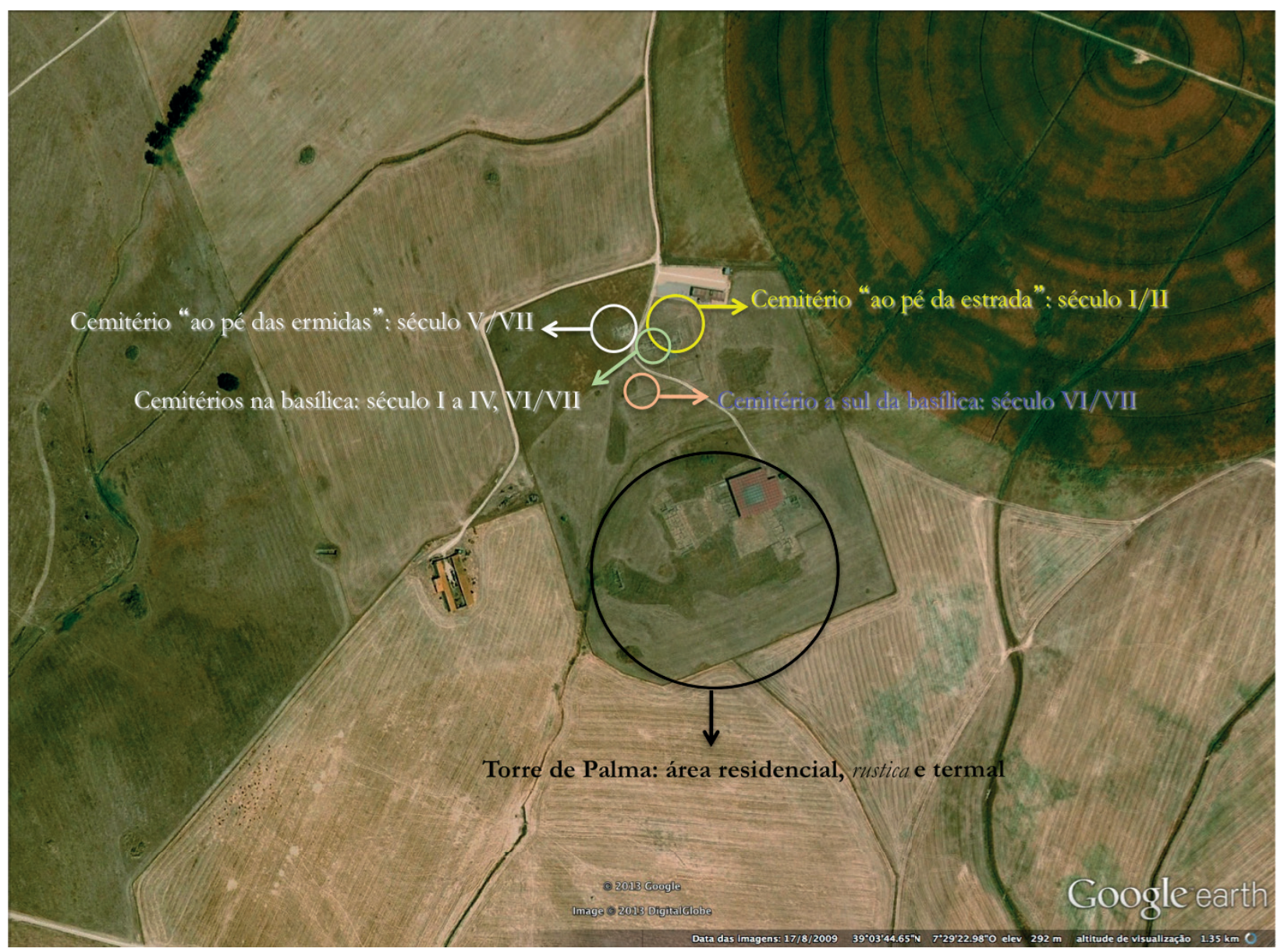

3. Localização das necrópoles de Torre de Palma (@ 2018 Google Earth).

3. Embora seja muito complexo analisar uma informação de campo que está insuficientemente documentada, a referência a duas sepulturas distintas que apresentam espólio tipologicamente diferente do anterior leva a crer que poderão existir pelo menos duas tumulações do século II. Na verdade, os dados conhecidos sugerem a presença de várias tumulações de cronologia alto-imperial, que ocupariam a mesma área do designado campo de urnas ${ }^{37}$.

4. Foram identificadas tumulações em número indeterminado, mas que podemos situar entre $25 \mathrm{e}$ 30. Com orientação distinta do conjunto anterior, situavam-se também em outro ponto, pois foram identificadas construções de um edifício indeterminado, e ainda um poço, sendo segura a atribuição destes elementos à época romana. Durante a escavação, foi perceptível que existiam duas fases de deposição funerária, ocorrendo a cotas distintas,

37 Vejam-se, por exemplo, as peças atribuídas ao arqueossítio da Chaminé e ilustradas em Viana e Deus, 1950b, 240, Fig. 9-b; Viana e Deus, 1958: 31-32, Fig.s 16 e 17. e também com ligeiras variações na tipologia das sepulturas. Este conjunto pode ser balizado entre os séculos III e IV, pois embora ocorra escassíssimo espólio, foram identificados alfinetes em osso e dois numismas do Baixo Império.

5. Foi ainda identificado um outro conjunto de inumações, na zona correspondente ao campo de urnas, e em número não inferior a 50 ocorrências, com diferentes tipologias construtivas, mas sempre em inumações de planta trapezoidal ou rectangular e com orientação regular. O espólio é muito escasso, tendo sido recolhido apenas um recipiente cerâmico, mas os elementos de adorno recolhidos - em especial brincos - apontam para uma ocupação dos séculos V-VII.

Desta forma, mais do que uma ocupação contínua, devemos pensar no arqueossítio da Chaminé como um espaço de referência para as distintas comunidades que ocuparam este território. Embora com hiatos na sua presença, o local foi percepcionado como um locus funebris ao longo de quase um milénio, 
verificando-se que reiteradamente se manifestou a preferência pela área como espaço sepulcral. É necessário ter em conta que o sítio não foi integralmente escavado, pelo que temos a visão truncada e poderão existir momentos de ocupação ainda não detectados, mas torna-se evidente que a atracção exercida pelo sítio foi quase constante. Da mesma forma, é notável que o espaço pertencente à villa do Carrão tenha sido guardado a alguma distância, como em Torre de Palma; os seis compartimentos identificados na escavação da pars urbana não mostraram sinais de tumulações e, embora não saibamos em que ponto se implanta a fase de enterramentos baixo-imperial que se encontra em meio a estruturas, parece ser seguro que a área principal de edificação se manteve como referencial sem intrusões (figura 4).

\section{III) caso de estudo: Torre das Arcas}

Mais uma extensa necrópole pertencente ao concelho de Elvas ${ }^{38}$, com um total reconhecido de 84 sepulturas (note-se que, mais uma vez, o local não foi integralmente escavado). Destas, 49 são de inumação e 17 são seguramente de incineração, com 18 situações indeterminadas. A escavação permitiu constatar a sobreposição topográfica de enterramentos, com a ocorrência de sepulturas de inumação sobre urnas cinerárias. Idêntico testemunho de um aproveitamento intensivo do espaço funerário são os ossários identificados, com 13 enterramentos contendo os restos mortais de mais do que um indivíduo.

As sepulturas 40, 43, 50 e 56 apontam para um terminus post quem da segunda metade do séc. II d.C. para a introdução da prática do rito de inumação naquela necrópole elvense. As sepulturas mais antigas, associadas à prática da incineração, remontam a meados do séc. I d.C., ainda que a maior parte dos enterramentos seja genericamente datável da segunda e terceira centúrias. Das inumações, 7 serão baixo-imperiais e 22 poderão ser tardias, por não apresentarem espólio, à excepção de escassos elementos de adorno, como uma pulseira de bronze sem decoração (figura 5).

IV) caso de estudo: Padrãozinho

Um total de 189 sepulturas individualizadas em quatro grandes momentos nesta necrópole do con-

38 Carneiro, 2014, vol. II, 190. Por comodidade, indicase a referência do volume respeitante ao corpus de sítios no Alto Alentejo, sendo que em cada entrada individual o leitor poderá encontrar referências específicas. celho de Vila Viçosa ${ }^{39}$. Tendo em conta, por um lado, as limitações do processo de escavação, e, por outro, a grande quantidade de espólio recolhido, percebe-se a dificuldade em destrinçar distintas fases e zonas de ocorrência, havendo ainda a situação da necrópole n. ${ }^{\circ} 3$, que, apesar dos topos de sepulturas aflorando à superfície, não terá sido escavada.

$\mathrm{Na}$ necrópole n..$^{-} 2$ foram identificadas 7 enterramentos correspondentes a incinerações da Idade do Ferro; na sequência diacrónica temos o núcleo n. ${ }^{\circ} 4$, com um total de 128 sepulturas de incineração que mostraram uma grande diversidade de espólio, em especial de artefactos metálicos. $\mathrm{O}$ conjunto encerra-se com a necrópole n. ${ }^{0}$ 1, composta de 54 sepulturas de inumação, das quais apenas 5 apresentando espólio, o que demonstra uma cronologia tardia (eventualmente posterior ao século V). Todos os núcleos se apresentam espacialmente próximos, embora individualizáveis, e distantes de uma área habitacional (na qual se referem silhares de granito e um capitel em mármore), que não foi por nós identificada em sucessivas visitas ao local.

\section{V) caso de estudo: Serrones}

Necrópole situada no concelho de Elvas e intervencionada por Abel Viana e António Dias de Deus. O número total de enterramentos cifra-se em 106, dos quais 31 pertencentes a uma fase de incineração, havendo nas inumações (41) também uma distinção entre deposições com alguns objectos e outras sem espólio associado (posteriormente, no decurso de trabalhos agrícolas, foi identificada um outro enterramento, confirmando que a necrópole não havia sido inteiramente escavada). Tal como em Chaminé, situa-se próximo do itinerário da via XII.

\section{VI) outras situações (menos explícitas)}

São de referir outros casos que parecem testemunhar uma continuidade na referenciação do espaço funerário. Contudo, por não terem sido objecto de escavações arqueológicas sustentadas, não é fácil comprovar tal interpretação.

Em algumas situações temos reaproveitamentos de epígrafes funerárias como elemento construtivo de sepulturas, indicando que a valoração original do primeiro enterramento ou a sua memória se terá perdido. Este tipo de situação foi registada em Horta do Pascoal (Crato) ${ }^{40}$, no qual Leite de Vasconcelos menciona o reaproveitamento de uma epígrafe

39 Carneiro, 2014, vol. II, 426-427; Rolo, 2016, 101-104. 40 Carneiro, 2014, vol. II, 142. 


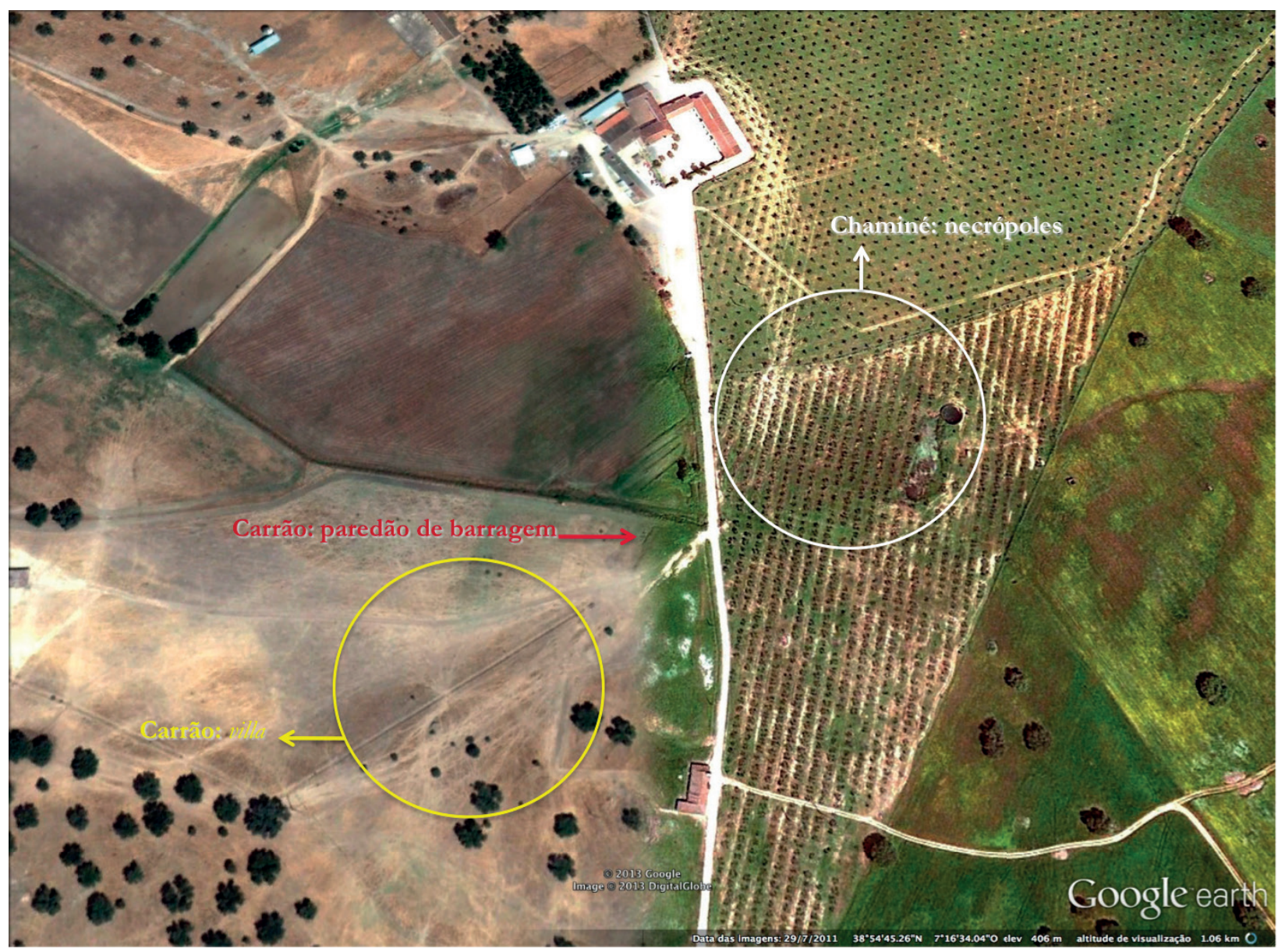

4. Localização da necrópole de Chaminé e villa do Carrão († 2018 Google Earth).

em um "cemitério antigo". Também em Camugem (Elvas) se documentou este processo: em três sepulturas baixo-imperiais ${ }^{41}$ identificadas, registou-se que uma apresentava duas epígrafes reaproveitadas como elementos da arquitectura funerária. Em todas estas situações, as inscrições apresentam também conteúdos de âmbito fúnebre, demonstrando que nas proximidades existiria uma necrópole.

Outros casos correspondem à sobreposição de enterramentos, em sequência estratigráfica. Tal ocorre em Tapada das Pinheiras (Ponte de Sor) ${ }^{42}$, onde uma sepultura de inumação se sobrepunha a uma incineração, embora os dados sejam insuficientes para uma interpretação dos tempos e modos de sucessão.

Uma situação ligeiramente distinta foi detectada na escavação da necrópole de Outeiro do Mouro (Fronteira $)^{43}$. No sopé da encosta foram identificadas

41 Carneiro, 2014, vol. II, 205.

42 Carneiro, 2014, vol. II, 389.

43 Carneiro, 2014, vol. II, 273-275. A escavação foi mais de trinta sepulturas de incineração, todas com espólio que pode ser balizado entre finais do século I d.C. e meados da centúria seguinte. Todavia, no topo da pequena elevação, assinalam-se duas sepulturas em caixa de lajes pétreas, sendo que a escavação do seu interior não permitiu recolher qualquer evidência, nem de âmbito osteológico, nem artefactual. Neste caso, temos o deslocamento do espaço funerário para uma implantação ligeiramente ao lado, o que se pode justificar pela perda de memória do espaço anterior, que não deveria ter sido dotado de grande visibilidade.

conduzida entre 2007 e 2011 por um dos signatários (A.C.) e os resultados permanecem, no essencial, inéditos e por publicar. Ver também Carneiro, 2015, 131-132. 


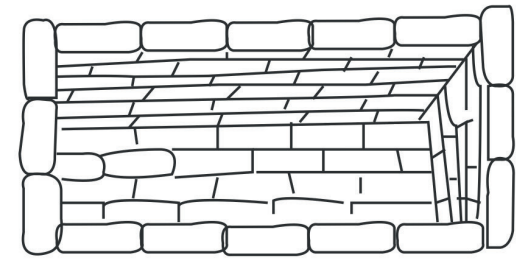

Sepultura 11

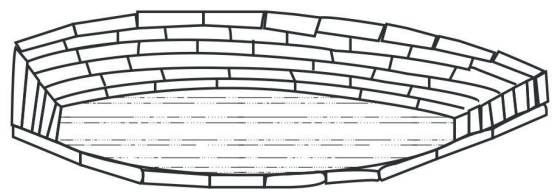

Sepultura 31

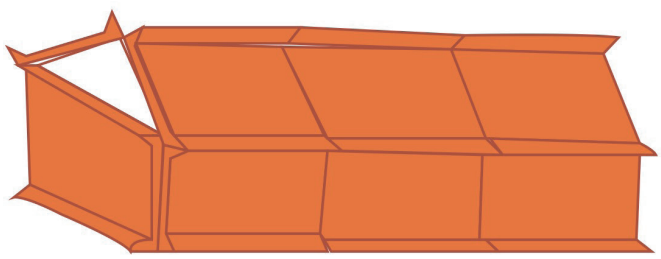

Sepultura 56
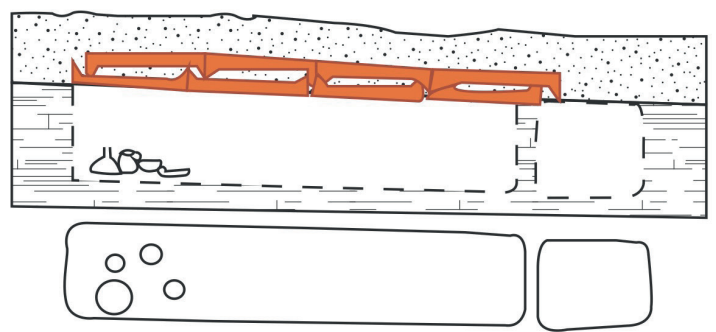

Sepultura 69

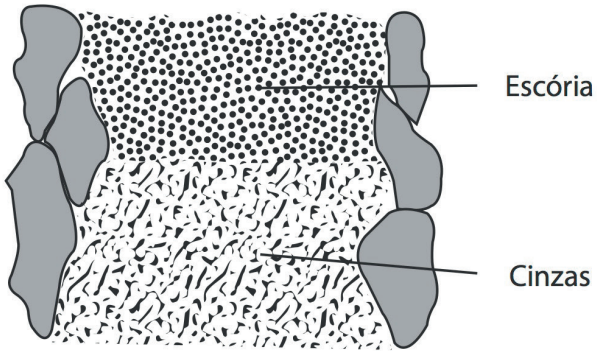

Sepultura 79

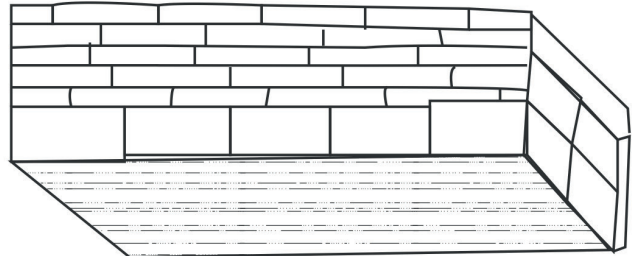

Sepultura 27

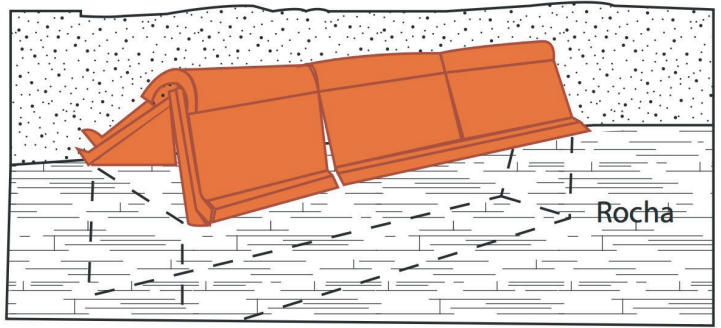

Sepultura 55

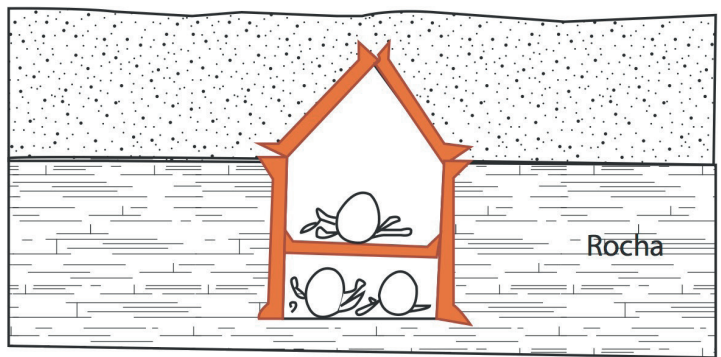

Sepultura 56

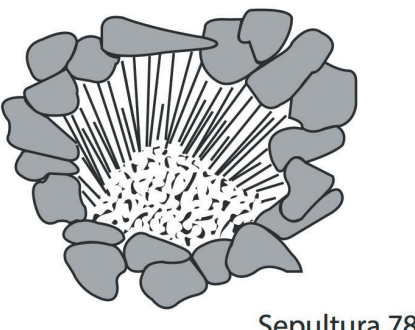

Sepultura 78

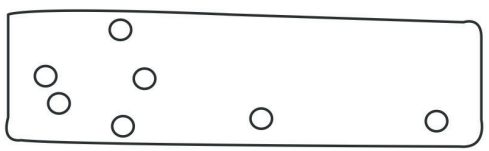

Sepultura 11

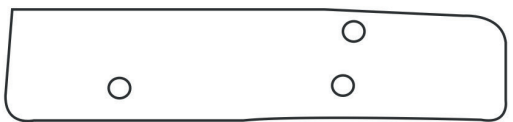

Sepultura 12

5. Principais tipos de tumulações documentados na necrópole de Torre das Arcas (Elvas) (Viana \& Deus, 1955, Fig. 2 - Adaptado V. Dias). 
4.2. Mudanças de uso: de habitação para tumulação

\subsubsection{Villae}

\section{I) na pars urbana}

A villa de Monte de S. Francisco (Fronteira) ${ }^{44}$ foi reconhecida no decurso de prospecções para a carta arqueológica municipal, sendo que a intensidade das leituras de superfície realizadas em múltiplas ocasiões permitiu definir prováveis áreas de uso funcional em distintos sectores do sítio. Foi por isso surpreendente que em 2014 tivesse sido identificado, no decurso de trabalhos agrícolas, uma sepultura de inumação, que foi depositada escavando o afloramento e que apresentava uma arquitectura tumular composta por potentes lajes de xisto, visto as grandes dimensões e o peso de cada uma. A intervenção arqueológica realizada em 2015 permitiu identificar três sepulturas idênticas, com quase total ausência de espólio (regista-se uma pequena conta de colar e fragmentos de cerâmica comum muito grosseira), que tornam difícil de balizar o momento da deposição funerária, embora se possa apontar para o século VI. Esta situação é particularmente sugestiva, pois em S. Francisco foram recolhidos numerosos fragmentos de terra sigillata clara norte-africana, em especial de fabricos $\mathrm{D}$, dominando as tipologias Hayes 50 e Hayes 61, de amplo leque cronológico, com produções que atingem meados do século VI (ocorrência de fragmentos de Hayes 93b e 97 como exemplares mais tardios). Ou seja, num curto espaço de tempo o perfil de ocupação muda radicalmente. É complexo definir em que sector da villa se implanta a necrópole, uma vez que na escavação não foi identificado qualquer elemento estrutural, mas a proximidade ao edificado parece evidente, visto que as casas atuais, situadas a menos de 20 metros, assentam sobre pavimentos de mosaico identificados desde há muito por curiosos locais.

II) Em áreas edificadas de funcionalidade incerta

Por ausência de escavações arqueológicas com metodologias de open area, várias situações identificadas não resultaram claras, quer quanto à funcionalidade das áreas estruturais identificadas, quer quanto à topografia de implantação das sepulturas que se colocam em fase posterior.

44 Carneiro, 2014, vol. II, 277-279.
Assim, podemos identificar alguns casos em que existem tumulações em áreas edificadas, embora a funcionalidade destas não seja discernível.

No caso de S. Salvador (Campor Maior) ${ }^{45}$, é evidente que estamos perante uma villa, em implantação privilegiada sobre o rio Xévora, situação que hoje coloca em causa a preservação de muitas estruturas, dada a proximidade do curso de água. A escavação realizada na década de 80 do século XX colocou à vista um grande peristilo, alinhado com o eixo do rio, rodeado por vários compartimentos que apresentam pavimentos de mosaico e pinturas murais, indicando um espaço de otium et contemplatio de acentuado requinte. Contudo, em época tardia, várias remodelações parecem indicar uma viragem na forma de percepção e utilização do local: alguns pavimentos são remendados com opus signinum, e restos de fauna sobre pavimentos parecem indicar uma ocupação de tipo squatter, sendo que alguns orifícios perfurando pavimentos de mosaico reforçam esta opinião. Em outra área, difícil de interpretar por não haver uma planta dos trabalhos realizados, identificaram-se quatro sepulturas, tendo sido escavada apenas a n. ${ }^{\circ} 1$. A recolha de um jarro de bocal trilobado aponta para cronologias do século V ou, mais possivelmente, do VI. Contudo, não são referidas evidências estruturais anteriores apenas um muro que "corta algumas sepulturas", o que pode estar relacionado com a edificação de uma capela do século XV no local. Desta forma, não é perceptível qual a área funcional escolhida para a implantação das sepulturas, somente a sua proximidade à área de prestígio da pars urbana.

Uma situação mais complexa foi detectada em Vale da Bexiga (Castelo de Vide) ${ }^{46}$. Neste caso, uma escavação feita sem qualquer critério metodológico colocou à vista um conjunto de sepulturas de inumação alinhadas com muros, mas não foi escavado o interior de nenhum compartimento, pelo que é inviável qualquer interpretação. As cinco sepulturas identificadas seguem o alinhamento de estruturas, mas não é perceptível a funcionalidade dos muros, nem o seu enquadramento. Note-se que o sítio é classificado como villa, todavia não existem indicadores seguros que o comprovem, sendo que o único elemento arquitectónico de prestígio daqui proveniente é um colunelo de época visigótica.

45 Carneiro, 2014, vol. II, 91-95.

46 Carneiro, 2014, vol. II, 124-125. 
Em Monte da Ovelheira (Elvas) ${ }^{47}$, o único elemento deste sítio monumental que alguma vez foi intervencionado do ponto de vista arqueológico foi uma sepultura, por Abel Viana e António Dias de Deus. Apesar da profusão de vestígios que existem no local, a única referência dos autores prende-se com a implantação no meio de "um compartimento absidal", estando a sepultura coberta com lajes de mármore: "uma sepultura coberta por três lâminas de mármore pulido [sic]", "num dos ângulos do alicerce de uma sala com um dos lados em semicírculo" 48 . Visto que não existe outra informação nem qualquer planta publicada, não é possível adiantar qual o contexto de utilização deste espaço.

III) No edifício termal

Em Herdade dos Pombais (Marvão) ${ }^{49}$ regista-se o único caso conhecido no Alto Alentejo - mas frequente em outros pontos de Império - de tumulações aproveitando a estrutura do edifício termal, que habitualmente é a primeira área a ser desfuncionalizada no âmbito das villae. A zona do hipocausto, ainda com os arcos em bom estado de preservação, é necropolizada em torno ao século $\mathrm{IV}$, rasgando muros sem cuidar das pré-existências. Referências a ossos de animal de grande porte podem indicar que o local também foi utilizado como lixeira ou área de despejos. As deposições irão perdurar até, pelo menos, ao século $\mathrm{V}$, como se comprova pela presença de fragmentos de terra sigillata clara D e "pré-luzente", havendo ainda um fragmento de lucerna com chrismon no disco, embora pareça mais provável que este conjunto artefactual indique actividade na pars urbana do sítio, visto que não provêm de qualquer sepultura. $\mathrm{O}$ número de inumações ascende a 32 , indicando uma comunidade numerosa e que ocupa o local durante algum tempo, havendo ainda a registar um sarcófago em granito, deslocado para a extrema da propriedade.

\subsubsection{Outros sítios}

Para além das villae, registam-se outros modelos de povoamento no Alto Alentejo. A frequência de tumulações em momentos tardios é até superior ao que ocorre nos sítios mais opulentos, pelo que é relevante enumerar as situações registadas.

47 Carneiro, 2014, vol. II, 205-206.

48 Deus, Louro e Viana, 1955, 573.

49 Carneiro, 2014, vol. II, 299-302.

\subsubsection{Povoados abertos}

Em Monte da Nora (Elvas) ${ }^{50}$, as escavações extensivas revelaram um povoado que evolui em continuidade desde a segunda metade do século II a.C.. Com sistema de duplo fosso, o espaço habitado converte-se, em época romana, num modelo próximo de uma aldeia, com dois fornos de produção cerâmica e um lagar, possivelmente para uso comunitário, sem evidência de planificação ou proto-urbanismo na malha de habitações. A última fase, que ocorre durante o final do século V ou VI, é marcada pela transformação da zona habitacional em necrópole, com um conjunto de sepulturas alinhadas de acordo com o rito cristão, e que indiscriminadamente vão ocupar toda a área disponível.

Ao longo da Barragem da Póvoa (Castelo de Vide $)^{51}$ verifica-se a presença de numerosos espaços de habitação, de acordo com um modelo disperso ao longo de um curso de água (cerca de cinco hectares). É complexo avaliar o perfil de povoamento no local, onde em algumas habitações se nota a reutilização de materiais arquitectónicos de época romana, embora todos os compartimentos apresentem uma cultura material inequivocamente de cronologia imperial. Apesar da proliferação de sepulturas escavadas na rocha nas imediações, existe um momento de tumulação anterior, pois em algumas habitações encontram-se inumações estruturadas com grandes lajes de granito, à semelhança das da necrópole próxima de Azinhaga da Boa Morte. A escavação do interior destas estruturas não revelou qualquer espólio.

A situação é muito semelhante em Monte das Freiras (Arronches) ${ }^{52}$. Também neste caso temos um povoado disperso de habitações espalhadas ao longo do leito de um rio (hoje com um lago artificial criado por uma barragem). As numerosas habitações dispõem-se, em sucessão, ao longo da paisagem, a par de evidências de ocupação posterior, conforme atestam as frequentes sepulturas escavadas na rocha. As sepulturas são compostas por cistas rectangulares formadas por lajes de granito colocadas em cutelo, havendo ainda algumas com tampas conservadas. Neste caso, contudo, as sepulturas encontram-se ao lado das habitações, e não no seu interior. A proximidade espacial é evidente, mas a tumulação encontra-se fora das áreas edificadas.

50 Carneiro, 2014, vol. II, 190-192.

51 Carneiro, 2014, vol. II, 126-127.

52 Carneiro, 2014, vol. II, 45-46. 
4.2.2.2. Unidades de média dimensão (casal agrícola [?])

Em 1962 decorreu uma intervenção arqueológica não documentada no sítio de Curral de Sampão (Monforte $)^{53}$. Os trabalhos estiveram inseridos no quadro das escavações promovidas pelo Museu Nacional de Arqueologia na villa de Torre de Palma, do qual Sampão parece ser um sítio-satélite, dada a proximidade entre ambos. Deste modo, embora as estruturas arquitectónicas não tenham sido caracterizadas nem descritas, o mais provável será tratar-se de uma unidade de povoamento secundária, na dependência ou vizinhança da grande villa próxima. Note-se contudo, que é atribuído ao sítio um tesouro numismático de 377 exemplares, sendo o mais recente de Diocleciano, encontrados em contexto de aforro ${ }^{54}$, eventualmente relacionados com o "poço antigo onde apareceu uma moeda de Graciano" que consta da primeira menção ao sítio ${ }^{55}$. Assim sendo, e não obstante este dado isolado revelar-se insuficiente para avaliar que tipo de sítio existiu no local, deve ser considerado como um relevante indicador de capacidade aquisitiva. Seja como for, assinala-se que as sepulturas estão no meio de estruturas, tendo sido encontradas pelo menos onze inumações de uma "necrópole visigótica", com fíbulas e os crânios a Oeste, o que indica uma cronologia entre o século VI e o VII.

\subsubsection{Templos}

Olhando para uma área mais abrangente da província da Lusitania, detecta-se outra realidade que importa considerar. Trata-se da utilização de espaços de culto que em época cristã são reconvertidos em locais de enterramento ${ }^{56}$.

No caso de S. Cucufate (Vidigueira), cerca de quinze sepulturas irão implantar-se no interior da estrutura cultual (no períbolo mas nunca na cella) e na sua envolvente, demonstrando que a estrutura funciona como elemento referente na organização do espaço funerário. $\mathrm{O}$ mesmo fenómeno sucede em Milreu (Faro), onde se procede à basculação da área funerária. A villa tinha dois mausoléus e uma área de necrópole a alguma distância do edificado, mas em momento tardio os enterramentos vão confluir para a zona do até então temenos.

53 Carneiro, 2014, vol. II, 336-337; ver também Carneiro, 2015, 127.

54 Ruivo, 2008.

55 Vasconcelos, 1927-1929,200.

56 O tema foi recentemente tratado em Bernardes, 2017.
4.3. A nova geografia funerária: sarcófagos e tumulações privilegiadas (ad sanctos)

As alterações trazidas em fase tardo-antiga, em particular sob o influxo cristão, que origina novas concepções sobre o modo como a passagem para a dimensão post mortem deve ser tratada, manifestam-se de modo claro na Lusitania e, em particular, na região do Alto Alentejo. Neste meio rural, cresce a proeminência social de protagonistas com algum tipo de ascendente, os illustris vir ou vir honestus, como designados nos textos e na epigrafia da época. É em torno destas figuras que os rustici vão procurar a última morada, originando-se uma topografia funerária orientada em função destes interesses imediatos, visto que os cânones emanados dos concílios eclesiásticos só mais tarde irão deliberar sobre os procedimentos de organização do espaço funerário. Não será de estranhar, portanto, as constantes hesitações e confusões, onde vemos a continuidade nas práticas pagãs ou a sua mescla com os novos hábitos, situação que o primeiro concílio de Elvira procura começar, desde logo, a combater ${ }^{57}$.

Uma das manifestações desta forma de entender as novas dinâmicas sociais, religiosas e espirituais, será a polarização tumular em torno de uma sepultura privilegiada, aproximando-se ao fenómeno da tumulatio ad sanctos. No território do Alto Alentejo, será também a expressão quantitativamente mais influente das alterações registadas entre o século V e o VII, embora seja difícil de definir com clareza os ritmos e formas deste processo. Note-se ainda que, sob a aparente uniformidade deste processo, uma leitura atenta permite identificar algumas variações relevantes, razão pela qual individualizamos a análise.

\section{I) caso de estudo: Terrugem}

Sítio intervencionado por Abel Viana e seus colaboradores, aquando das explorações nas necrópoles de Elvas. Embora objecto de uma pequena escavação de emergência, o caso de Terrugem torna-se muito relevante para o entendimento destes processos de transformação simbólica da paisagem rural $^{58}$.

A necrópole implanta-se sobre um sítio de ocupação anterior. Os escavadores são prudentes na interpretação do local, não utilizando o termo villa,

57 Arce, 2006, 120.

58 Carneiro, 2014, vol. II, 203-204. 

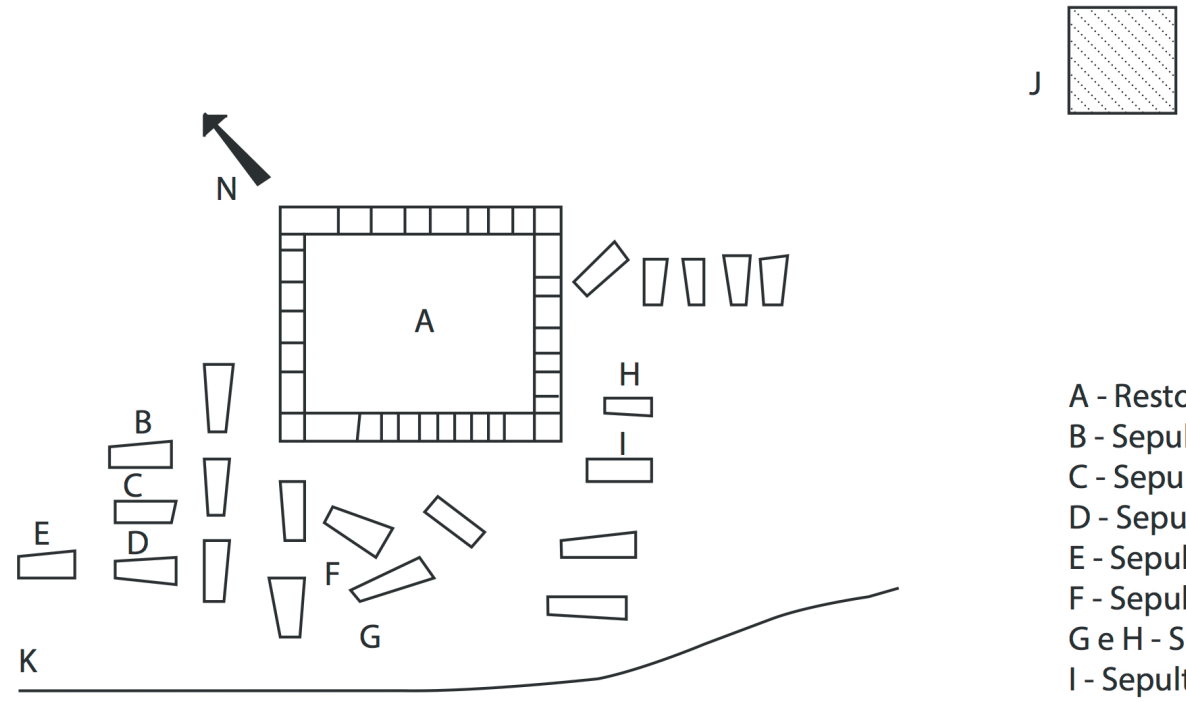
A - Restos do edifício
B - Sepultura com 2 crânios
C - Sepultura com 5 crânios
D - Sepultura com 7 crânios
E - Sepultura com fíbulas
$\mathrm{F}$ - Sepultura com 2 esqueletos
$\mathrm{G}$ e H - Sepultura de criança
I - Sepultura em mármore
J- "Monte" de Santo António
$\mathrm{K}$ - Linha de água

6. Planta geral da necrópole da Terrugem (Elvas) (Viana, 1950, Fig. 19 - adaptado V. Dias).

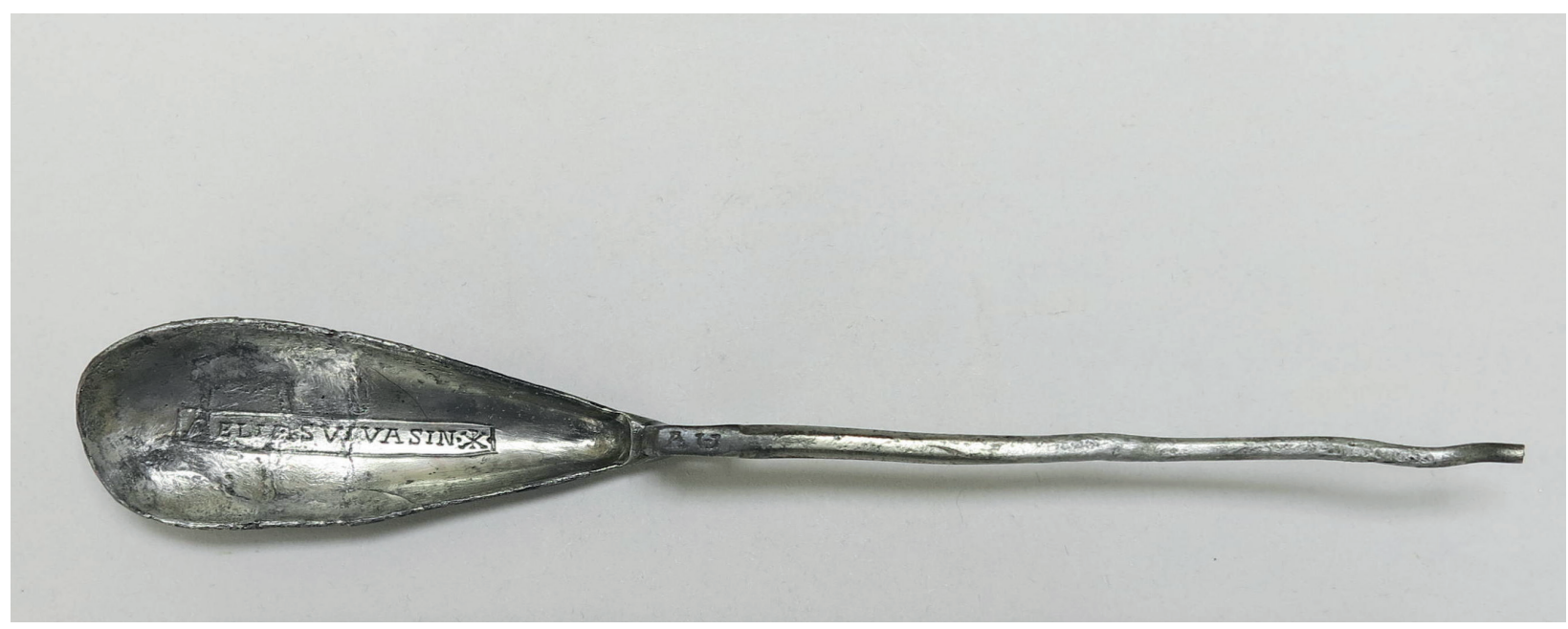

7. Colher proveniente de sepultura da Terrugem (CME Arq n. ${ }^{\circ}$ Inv. 2676; Foto M. Rolo).

e realçando a extensão dos vestígios, pelo que se poderá pensar em outra tipologia de sítio, eventualmente relacionada com o itinerário da via XII, que passa próximo. Embora o sítio tenha sido intervencionado com "algumas ligeiras sondagens que acusaram a presença de alicerces de outros edifícios" 59 , os indicadores mais relevantes foram obtidos a partir da sondagem que revelou parte da estrutura de um caldarium, onde ainda eram visíveis os arcos de tijolo, além de canalizações em cerâmica e uma coluna de mármore com $1,80 \mathrm{~m}$.

59 Deus, Louro e Viana, 1955, 572.
Neste contexto instala-se, à distância de cinco metros, uma necrópole com 30 sepulturas de inumação $0^{60}$, de formato trapezoidal e heterogéneas nos padrões construtivos. $O$ dado mais relevante, contudo, é o facto de rodearem um edifício de planta rectangular, quase quadrada, construído em sólida silharia granítica que assentava sobre duas moedas de bronze perfuradas ${ }^{61}$, colocadas em jeito de propi-

60 Manuel Heleno, que visitou o local, refere este número (Heleno, 1951, 94).

61 Deus, [s.d.], p. 5 (documento constante do Arquivo da Fundação Casa de Bragança). 
ciação. Apesar de inclassificáveis no seu estado actual, a fraca qualidade do metal dos numismas remete-nos para uma cronologia tardia, possivelmente de séc. IV d.C.. A construção do edifício não deverá, portanto, ser anterior a esta centúria. O interior do edifício não é descrito, mas as plantas publicadas mostram a variedade de orientações das sepulturas, que se acumulam procurando o contacto com o edifício ${ }^{62}$. Várias sepulturas continham ossários, documentando uma prática de inumações constantes. Entre o espólio recolhido, merece destaque uma colher de prata com a inscrição AELIAS. VIVASIN (chrismon); sendo a sua tipologia romana, o carácter paleocristão documenta uma utilização em torno ao século $\mathrm{V}$, similar aos brincos de remate poliédrico provenientes do local.

Resta, portanto, saber a função do edifício de planta quase quadrangular que serve como elemento polarizador do local. Descartando o uso como templo cristão, que não se coaduna com os dados existentes, e assumindo a sua fundação em momento tardio, terá sido um mausoléu que perpetuou a sua função de locus funebris durante os momentos posteriores? (figuras 6 y 7 ).

\section{II) caso de estudo: Silveirona}

Uma situação na essência semelhante à anterior $^{63}$. Este sítio do concelho de Estremoz foi intervencionado em data mais recuada, decorrendo os trabalhos em 1934. Neste caso identificaram-se fundações de momento imperial, sendo interpretadas como pertencentes à pars rustica de uma villa, essencialmente pelo espólio recolhido, com peças de funcionalidade agrícola. No meio destes alicerces irá instalar-se um conjunto de tumulações que se polarizam em torno de uma estrutura quadrangular que não parece ser de época romana, mas contemporânea destes enterramentos. No entanto, note-se que a alguma distância (300 metros, segundo Manuel Heleno) foi reconhecida uma extensa necrópole de época imperial com, pelo menos, 86 inumações e incinerações, de abundante e variado espólio. Desta forma, embora não havendo sobreposição topográfica, algumas sepulturas apresentam continuidade espacial, e manifesta-se, de modo

62 O canon 18 do I concílio de Braga (563) apresenta a proibição de os fieis procederem aos enterramentos no interior das basílicas martiriais, mas autoriza as tumulações encostadas às suas paredes: si necesse est, de foris circa murum basilicae. (Vives, 1963, 75).

63 Carneiro, 2014, vol. II, 230-235. pleno, uma pré-existência sepulcral anterior, sendo que algumas inscrições são reaproveitadas nos túmulos mais recentes.

A necrópole de Silveirona é mais conhecida pela sua fase de tumulação tardo-antiga. Registam-se 35 sepulturas, embora se reconhecessem mais de 50, pois a escavação decorreu em contexto de alguma destruição causada por trabalhos agrícolas e actos de vandalismo. Estas inumações tendem a aproximar-se de uma estrutura quadrangular, fortemente construída, que tem em seu redor (pelo menos na área intervencionada, visto que uma parede não terá sido escavada) um conjunto de sepulturas que, como em Terrugem, não apresenta particular organização. Da mesma forma, a diversidade de esquemas na arquitectura tumular é considerável.

Algumas particularidades de Silveirona são notáveis. Por exemplo, o facto de no interior da estrutura quadrangular se encontrar um marco miliário, com datação atribuída a 317 (corroborada por moedas de Constantino). O que faz um elemento honorífico importante no centro de uma necrópole tardia é de difícil explicação, embora seja admissível que nas proximidades passe uma via que, pelo menos, teria uma relevância secundária. Apesar do espólio ser escasso, recolheu-se um fragmento de cerâmica comum com iconografia cristã, representando uma folha de palma e peixe (com forma imitando os recipientes Hayes 44).

Mas sobretudo, o que chama a atenção é a rica documentação epigráfica, que permite um raro vislumbre da população inumada nesta fase. Acresce o facto de o intervalo cronológico ser curto - 513-544, apenas uma geração - e de as denominações permitirem perceber o modo como esta comunidade apresentava uma forte hierarquização, patente também no momento da morte. A este respeito, é paradigmático que a figura de Sabinus, nomeado como vir honestus, ocupe a posição central na contiguidade à estrutura quadrangular, assumindo um óbvio lugar de destaque. Da mesma forma, as outras pessoas com inscrição própria ocupam outras posições de grande centralidade, havendo ainda a registar o caso de dois sarcófagos que, embora sem epitáfio, também estão junto da estrutura polarizadora. Deste modo, o recinto quadrangular assume uma importância incontornável no ordenamento topográfico da necrópole que, por sua vez, reflecte também a condição/importância social desta população, tumulada de acordo com a representatividade que teria no quotidiano. Neste feixe de raciocínios, e descartando uma função religiosa do edifício, que não 
parece plausível pela inadequação da sua planta, terá de ser considerada a hipótese de aqui se situar uma tumulação ad sanctos na qual o marco miliário, símbolo do prestígio imperial, reforça o papel e condição honorífica do tumulado. Certo, contudo, é que, ao invés de Torre de Palma, que apresenta uma continuidade que transcende em muito o período cronológico aqui considerado e se transporta para a Idade Média, em Silveirona (como em Terrugem) a relevância dos sepultados não dota a necrópole de um estatuto que a permita perdurar no tempo enquanto local de veneração. Mesmo que aqui tenha existido uma basílica e um baptistério, como alguns elementos arquitectónicos o indiciam, os dados apontam para que, em torno ao século VII, a ocupação se extinga neste local.

III) caso de estudo: São Pedro dos Pastores

Uma das situações mais interessantes para análise situa-se no sítio conhecido como Defesa de S. Pedro ou S. Pedro dos Pastores, no concelho de Campo Maior ${ }^{64}$. Os indicadores relativos à passagem de uma via, possivelmente a XIV do Itinerário de Antonino, são sugestivos, essencialmente pela presença de dois marcos miliários. Desta forma, a relação do ponto de povoamento com a passagem da via levou a que o sítio fosse interpretado como vicus ou mansio (nesse caso podendo corresponder a $A d$ Septem Aras), sendo que, tal como nos dois casos anteriores (nos quais, relembre-se, também existe relação com marcos miliários), há a considerar a importância destes lugares como sítios de passagem, o que reforça a importância da função de $m e$ moria dos sepultados em inumações privilegiadas. Ou seja, nestes sítios a ligação entre a importância dos inumados e as vias é indissociável.

A indefinição sobre o perfil de povoamento de S. Pedro dos Pastores é relevante para a interpretação dos fenómenos de transformação que ocorrem a partir do século $\mathrm{V}$, impedindo-nos de perceber a real extensão das mudanças. Todavia, as dúvidas resultam sobretudo do modo como o sítio tem sido intervencionado: em sondagens arqueológicas parciais, com diferentes arqueólogos e lógicas de trabalho, sem continuidade ou uma metodologia comum, o que muito dificulta o entendimento das realidades existentes. Tendo estes pressupostos em mente, tentemos alinhar a informação disponível.

O sítio apresenta um estabelecimento termal, em relativo bom estado de preservação, e um conjunto de compartimentos articulados em torno de

64 Carneiro, 2014, vol. II, 95-100. um peristilo. Um pórtico permite a comunicação entre alguns dos espaços. Merece referência o facto de não serem conhecidos indicadores de prestígio, como pavimentos em mosaico ou elementos arquitectónicos em mármore (embora exista um capitel coríntio recolhido em outro ponto do sítio), mas regista-se a presença de revestimentos parietais em estuque pintado. Haveria também um conjunto de degraus que indicam a existência de um segundo piso, sendo na proximidade desta escada que se irá instalar uma sepultura em momento posterior, o que parece sugerir que este acesso já não estaria activo, e que os circuitos de passagem no interior do sítio teriam sido reformulados.

Em determinado momento, um destes compartimentos, designado de B, é remodelado, encurtando as suas dimensões, para conter um sarcófago de grande tamanho, revestido por inteiro com lajes de mármore, aparentemente em contexto de reaproveitamento por remoção de algum piso, embora todos os pavimentos do sítio que foram postos a descoberto em escavação sejam revestidos a tijoleira ou opus signinum. As reformas do compartimento dotam o sarcófago de grande centralidade e evidente destaque, promovendo o "encurtamento" da sala, o que aponta para a existência de um espaço de tipo mausoléu. O seu interior apresentava um esqueleto de sexo feminino, ainda em excelente estado de conservação. No compartimento ao lado, designado de C, encontram-se duas sepulturas, e em torno da sala principal espalham-se outras tumulações dispersas, somando um total de doze inumações registadas para além do sarcófago. Todas as restantes apresentam um evidente menor investimento construtivo, visto que são em lajes de pedra ou tijoleira, completamente distintas do enterramento em sarcófago que polariza o espaço. Tal como na tumulação em destaque, não é feita qualquer alusão a espólio, depreendendo-se que não foram recolhidos elementos associados.

Em resumo, temos um edifício com relativa imponência, que tanto pode prestar funções viárias próximo de um itinerário principal, como assumir funções de representação. Em dado momento, uma tumulação obriga a reformas construtivas para que o até então espaço de habitação possa agora acolher a sepultura privilegiada. A remodelação do espaço implica a redução do compartimento de modo a conceder destaque ao sarcófago, e na sala anexa, acessível por um pórtico, instalam-se duas outras tumulações, bastante mais modestas. Em torno ao 
peristilo irão acomodar-se várias outras inumações, mas nenhuma a curta distância do enterramento principal, que manterá sempre o seu destaque no conjunto. Como nota relevante a acrescentar, foram identificados níveis de incêndio e de derrube motivado por causas violentas, situação que terá ocorrido entre o momento de ocupação imperial e a fase tardo-antiga, e que terá propiciado as alterações construtivas e de uso do espaço edificado.

IV) outros casos: os sarcófagos e a monumentalização da morte (Eira do Peral)

Sem um contexto arqueológico determinado de forma tão clara como nas anteriores situações, merece mesmo assim referência a situação de Eira do Peral, Monforte ${ }^{65}$. Os dados são coligidos a partir de uma notícia antiga: "quando uns trabalhadores procediam aos trabalhos de remoção de pedras, encontraram, um pouco abaixo da superfície, um túmulo de mármore branco, contendo uma ossada humana que, pelo avançado estado de deterioração, deve datar de mais de 100 anos. No local onde hoje estivemos há vestígios, em volta do sepulcro, de ali ter existido qualquer edifício, talvez uma igreja, pois descobrem-se outras pedras, umas de granito e outras de mármore, trabalhadas, e ao mesmo nível do topo do sepulcro nota-se em toda a volta uma camada de cal amassada que parece indicar o pavimento de uma casa. Os ossos encontram-se desligados mas todos de fácil reconhecimento. Os da cabeça estão aos bocados, como todos os outros." 66

O sarcófago será o mesmo que posteriormente foi recuperado por A. Dias de Deus e seus colaboradores, encontrando-se hoje em dia no Museu Municipal de Elvas. Aquando da identificação, salientou-se a existência de sepulturas em torno da estrutura, cobertas com lajes de mármore, e contendo ossos no seu interior. Quatro silhares in situ marcavam os cantos de um compartimento de grandes dimensões, com evidente destaque na paisagem e próximo de um caminho antigo, onde no atravessamento da ribeira existe uma calçada (figura 8).

A monumentalização da morte expressa na deposição em sarcófagos é um traço característico dos territórios mais plenamente inseridos nas esferas da romanidade e próximos dos circuitos viários. Quando nos afastamos para áreas mais periféricas não os detectamos. No Alto Alentejo, apenas temos sarcó-

65 Carneiro, 2014, vol. II, 352.

66 Autor identificado como "C.", jornal Brados do Alentejo de 18/09/1949, ano XVIII, $n^{\circ}$ 951, 6.

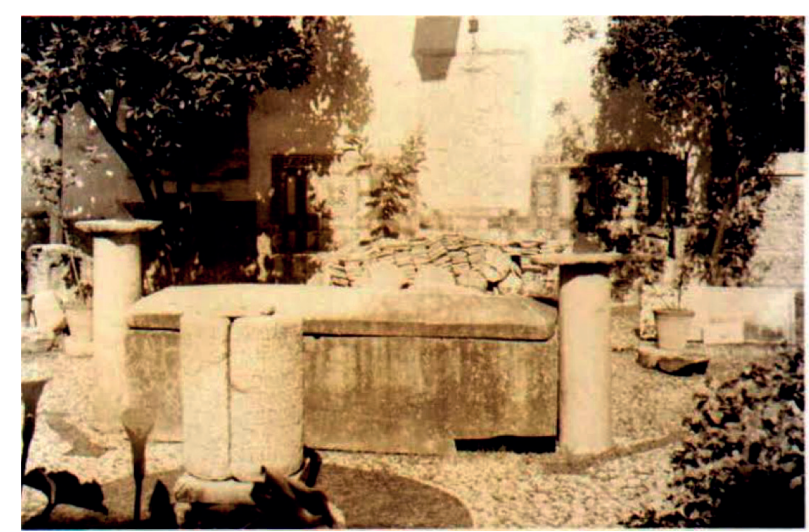

8. Sarcófago e colunas de Eira do Peral (Foto Arquivo da Biblioteca Municipal de Elvas).

fagos encontrados em opulentas villae do concelho de Elvas (Monte do Paço, em granito, e Botafogo, em mármore), além dos já mencionados casos de $\mathrm{S}$. Pedro dos Pastores (Campo Maior) e Pombais (Marvão).

5. O FIO DO TEMPO: NOVOS MODELOS DE TUMULAÇÃO

É muito complexo definir com rigor as sequências evolutivas e perceber o modo como os padrões evoluem. A grande maioria das escavações realizadas em contextos tardo-antigos na área de referência foi feita sem metodologias modernas, e/ou os resultados não foram devidamente interpretados porque as intervenções decorreram em contexto de emergência ou sem os meios adequados. Procurar paralelos em outras regiões é também incorrer em possíveis enganos, porque os ritmos e formas de evolução são muito variáveis de área para área. Acresce ainda o facto de, na esmagadora maioria das situações, a cultura material e/ou os indicadores cronológicos serem escassos ou inexistentes, o que dificulta uma percepção clara das sequências de passagem. A exuberância epigráfica de Silveirona é uma ocorrência excepcional, pois em geral a dificuldade de ler o tempo de uma forma clara é um dos principais constrangimentos para a análise deste processo. Por último, note-se que a escassa área intervencionada impede uma leitura mais rigorosa das situações e contextos. Se em Terrugem e S. Pedro dos Pastores tivessem sido obtidos resultados com planimetrias mais amplas, seguramente que os dados para análise seriam completamente diferentes e, quer a noção das pré-existências, quer a análise topográfica de onde se implantam os sarcófagos e estruturas polarizadoras, poderiam trazer-nos dimensões muito mais ricas para a análise. 
Seja como for, outros modelos de tumulação surgem no registo arqueológico em momentos ainda mal esclarecidos, fazendo com que a evolução prossiga, e deste modo, novas formas simbólicas de percepção da morte tenham lugar. É o caso das necrópoles em locais ex novo, sem ligação com pré-existências, e que evidenciam novas formas de entendimento do território. Em certas zonas do Alto Alentejo, em especial áreas onde o povoamento romano é marginal ou pouco intenso, vemos necrópoles que parecem procurar a instalação em áreas escondidas ou pouco povoadas. No caso de Santa Marinha (Castelo de Vide ${ }^{67}$, por exemplo, vemos como uma pequena necrópole constituída por caixas formadas por lajes de granito irregulares e grosseiramente talhadas se instala em meio a uma paisagem onde a densidade de povoamento é baixa ou quase nula. Datadas de finais do século VI ou inícios do VII pelo espólio cerâmico recolhido (essencialmente bilhas e jarros trilobados de fabrico grosseiro), a organização da necrópole já se afasta do caos de orientações e alinhamentos que caracteriza os exemplos anteriores, parecendo existir uma definição de recinto funerário que as enquadra. $\mathrm{O}$ panorama, porém, é de uma evidente rusticidade, com os afloramentos graníticos em volta favorecendo o ocultamento desta comunidade. Os 16 enterramentos configuram a existência de um grupo distante dos principais circuitos de transacção. No território de Castelo de Vide, outros exemplos similares reforçam esta impressão.

Em breve, outros modelos de tumulação chegam, começando a espalhar-se por toda esta área regional. As sepulturas escavadas na rocha mostram novas formas de percepção do mundo da morte, e também novas formas de apropriação do território. Irão espalhar-se pelo Alto Alentejo, configurando uma evolução para outro tipo de padrão, cada vez mais distante do mundo romano.

\section{BibLIOGRAFIA}

Almeida, F. de (1972-1974), "Torre de Palma (Portugal). A basílica paleocristã e visigótica”, $A r$ chivo Español de Arqueología, 45-47/125130, 103-112.

Almeida, Mำ J. de (2000), Ocupação rural romana no actual concelho de Elvas, Dissertação de Mestrado apresentada à Faculdade de Letras

67 Carneiro, 2014, vol. II, 132. da Universidade de Coimbra, 2 volumes [policopiado].

Arce, J. (2006), “Fana, templa, delubra destrui praecipimus: el final de los templos de la Hispania romana", Archivo Español de Arqveología, 79, 115-124.

Bernardes, J. P. (2017), “A transformação do espaço funerário no Ocidente entre os séculos IV e VI. Ambiguidades e loci sepulturae em espaços rurais no Sul da Lusitânia: o caso dos templos". Arqueologia da transição: entre o mundo romano e a Idade Média (A. Carneiro e C. Teixeira, Coords.), Coimbra, IUC (Humanitas Supplementum 44), 367-386.

Carneiro, A. (2005), "Espólio da necrópole romana dos Pocilgais (Fronteira): Uma leitura integrada”, O Arqueólogo Português, Série IV/23, 283-320.

(2014), Lugares, tempos e pessoas. Povoamento rural romano no Alto Alentejo, Imprensa da Universidade de Coimbra (Humanitas Supplementum 30), Coimbra.

https://digitalis.uc.pt/ptpt/livro/lugares_tempos_e_pessoas_povoamento_rural_romano_ no_alto_alentejo_vol_i;

https://digitalis.uc.pt/ptpt/livro/lugares_tempos_e_pessoas_povoamento_rural_romano_ no_alto_alentejo_vol_ii.

(2015), "Morre-se há muito tempo sobre a terra. Topografia funerária e sociedade no Alto Alentejo em época romana", Actas do II Congresso de Arqueologia de Transição: o mundo funerário, CHAIA, Évora, 125-139.

Chavarría Arnau, A. (2007), El final de las villae en Hispania (siglos IV-VIII), , Brepols Publishers, Bibliothéque de l'Antiquité Tardive, 7, Turnhout.

Deus, A. D. (S.D.), Descobertas arqueológicas no concelho de Elvas [documento dactilografado; policopiado], Disponível no Arquivo da Fundação da Casa de Bragança (AFCB).

Deus, A. D., Louro, Pe H. S. e Viana, A. (1955), "Apontamento de estações romanas e visigóticas da região de Elvas (Portugal)”, III Congreso Nacional de Arqueologia, Zaragoza, 568-578.

Frade, H. e Caetano, J. C. (1993), "Ritos funerários romanos no nordeste alentejano”, II Congresso Peninsular de História Antiga, Faculdade de Letras da Universidade de Coimbra, Coimbra, 847-873. 
Garcia y Bellido, A. (1971), "Colheres romano-visigodos de la Península Hispánica”, Conimbriga, $X, 93-98$.

Heleno, M. (1951), “Arqueologia de Elvas. Notícia preliminar”, O Arqueólogo Português, Série II/I, 83-94.

(1962), "A villa lusitano-romana de Torre de Palma (Monforte)”, O Arqueólogo Português, Série II/4, 313-338.

IRCP = Encarnação, J. d' (1984), Inscrições Romanas do Conventus Pacencis, Coimbra, IAFLUC.

Jiménez Díez, A. (2006), "Contextos funerarios en la transición del mundo prerromano al romano en el sur peninsular", Anales de Arqueología Cordobesa, 17 (1), 67-98.

Mantas, V. (2000), "A sociedade luso-romana do município de Ammaia”, Sociedad y cultura en Lusitania romana (J.G. Gorges e T. Nogales Basarrate, Coords.), Junta de Extremadura, Mérida, 391-420.

Rolo, M. (2010), A necrópole romana da Rouca (Alandroal, Évora), Dissertação de Mestrado em Arqueologia apresentada na Faculdade de Letras da Universidade de Lisboa, 2 volumes [policopiado].

(2016), "Abel Viana e Vila Viçosa”, Actas da jornada Abel Viana (1896-1964) - paixão pela Arqueologia (M.J. Monge, Coord.), Fundação da Casa de Bragança, Vila Viçosa, 83-110.

(2017), "O contributo dos trabalhos de Abel Viana e António Dias de Deus para o conhecimento do mundo funerário romano no termo Sul do Alto Alentejo (Portugal) e o arqueossítio da Chaminé como caso de estudo", Cuadernos de Arqueología da Universidad de Navarra, 25, 57-89.

Ruivo, J. (2008), Circulação monetária na Lusitânia do século III, Dissertação de Doutoramento em Arqueologia apresentada à Faculdade de Letras da Universidade do Porto [policopiado].

Teichner, F. (2017), "Loci sepulcri in agro. La evidencia del proyecto VRB”, Las villas romanas de la Betica (R. Hidalgo Prieto, Coord.). Vol. I, Universidad Pablo Olavide, Sevilla, 551-574.

Ulbert, T. (1978), Frühchristliche Basiliken mit Doppelapsiden auf der Iberischen Halbinsel. Studien zur Architektur - und Liturgiegeschichte, Berlin.

Vaquerizo Gil, Desiderio -Ed.- (2002), Espacios y Usos funerarios en el occidente romano, Cor- doba.

(2011), "Espacios, usos y hábitos funerários en la Hispania romana: reflexiones y últimas novidades". Mors omnibus instat. Aspectos arqueológicos, epigráficos y rituales de la muerte en el occidente romano (J. Andreu, D. Espinosa e S. Pastor, Coords.), Bellatrix, I, Madrid, 191-231. Vasconcelos, J. Leite de (1927-1929) (1927-1929), "Antiguidades do Alentejo", O Archeologo Portugues, XXVIII, 158-200.

Viana, A. (1950), "Contribuição para a arqueologia dos arredores de Elvas", Trabalhos de Antropologia e Etnologia, 12 (3-4), 289-322.

(1955), "Notas da arqueologia alto-alentejana. (Materiais do Paço Ducal de Vila Viçosa)", A Cidade de Évora, 10/33-34, 5-28.

Viana, A e Deus, A. Dias de (1955), "Necropolis de la Torre das Arcas", Archivo Español de Arqueologia, 28/92, 244-265.

Vives, José -Ed.- (1963), Concilios visigóticos e hispanorromanos, Barcelona. 
